pijarskiego w Europie, w szczególności zaś dzialania poszczególnych prowincji zakonnych i procesu kształtowania się odrębnego zbioru przepisów regulujących organizację i program kształcenia. Krzysztof Maliszewski mówił natomiast o edukacji dla wspólnego świata w koncepcji Jana Amosa Komeńskiego, która według autora pozostaje ciekawym i ważnym impulsem dla rozwoju współczesnej myśli pedagogicznej, bo zaleca wychowanie, które polega na wyborze - wbrew różnorodności świata - tego, co najistotniejsze. Ostatni referat na obradach sekcyjnych przedstawiła Łucja Kabzińska. Mowa w nim była o udziale polskich pedagogów w międzynarodowych kongresach nauczycieli szkół średnich w okresie międzywojennym. A był on znaczący i wpływal na rozwój myśli pedagogicznej w naszym kraju, zwłaszcza w propagowaniu nowatorstwa dydaktyczno-metodycznego, tworzenie nowych programów nauczania i kształtowanie się ustroju szkolnego. W grupie najbardziej aktywnych uczestników tych zjazdów autorka wystąpienia umieścila nauczycieli-praktyków i nazwiska najwybitniejszych polskich pedagogów. Organizatorzy obrad sekcji XIV zapowiedzieli, że przedstawione referaty ukażą się w druku.

Edyta Glowacka-Sobiech

\title{
Międzynarodowa Konferencja Naukowa - „Szkolnictwo niepubliczne w Europie i w Polsce w XX wieku” (Łódź, 22 - 23 października 2001)
}

W dniach od 22 do 23 października 2001 roku odbyła się w Łodzi międzynarodowa konferencja naukowa nt. "Szkolnictwo niepubliczne w Europie i w Polsce w XX wieku”.

Organizatorem spotkania była Katedra Historii Wychowania i Pedeutologii Uniwersytetu Łódzkiego oraz Katedra Pedagogiki i Studiów Edukacyjnych Wyższej Szkoły Informatycznej w Łodzi. Współorganizatorami konferencji byli także: Zespół Szkół Prywatnych Mariana Woźniaka w Łodzi oraz Towarzystwo Oświatowe „Szkoła 2001" w Łodzi. Uczestnicy reprezentowali ośrodki naukowe z Warszawy, Opola, Poznania, Kielc, Gdańska, Szczecina, Krakowa, Katowic, Jeleniej Góry oraz Bratysławy i Łublany.

Celem konferencji był przegląd rozwiazań organizacyjnych, podstaw prawnych i merytorycznych działalności szkolnictwa niepublicznego różnych stopni w przeszłości i obecnie oraz próba określenia perspektyw jego rozwoju.

Otwarcia konferencji dokonał prof. Tadeusz Jałmużna, którego wystapienie stanowilo próbę zarysowania działalności szkolnictwa niepublicznego w Polsce. Następnie zgromadzonych uczestników konferencji i gości powitali Rektor Uniwersytetu Łódzkiego oraz Dziekan Wydziału Nauk o Wychowaniu Uniwersytetu Łódzkiego. Konferencję zaszczycili swoją obecnością i wystapieniami sponsorzy konferencji: Aniela Bednarek (Wyższa Szkoła Informatyczna w Łodzi) i mgr Marian Woźniak (Zespól Szkół Prywatnych w Eodzi).

W pierwszym dniu konferencji obradom przewodniczyli: prof. K. Bartnicka (Uniwersytet Warszawski) oraz prof. D. Koźmian (Uniwersytet Szczeciński). Wygłoszono 16 referatów. Dwa pierwsze referaty wygłoszone zostały przez gości zagranicznych. Pierwszy przedstawił prof. J. Psenak (Uniwersytet Komeńskiego - Bratysława) i poświęcony był szkolnictwu niepublicznemu w Słowacji w latach 1918-2000, drugi natomiast dotyczył szkolnictwa prywatnego w Słowenii i wyglosił go dr $\mathbf{M}$. Simenc (Instytut Pedagogiki - Lublana). Po interesujacych wystapieniach gości swój referat wygłosiła prof. O. Czerniawska (Uniwersytet Łódzki). Podjęła w nim problematykę dotyczącą wizerunku szkoły w aspekcie badań biograficznych. Działalność edukacyjna Zgromadzenia Małych Sióstr Niepokalanego Serca Maryi przedstawił w interesujący sposób w swoim wystapieniu prof. S. Gawlik (Uniwersytet Opolski). Kolejnym mówca był dr S. Majewski (Akademia Świętokrzyska), który wygłosił referat pt. „Prawno-organizacyjne podstawy funkcjonowania szkolnictwa prywatnego w II Rzeczypospolitej”. 
Kontynuacją tego interesującego wystapienia były rozważania dr E. Magiery (Uniwersytet Szczeciński) na temat ustawy o szkolnictwie prywatnym z 11 marca 1932 r. oraz ks. mgra E. Wieczorka o szkole wyznaniowej w nauczaniu Bpa Michała Klepacza.

Kolejne niezwykle ciekawe wystapienie dotyczyło prezentacji sylwetki T. Lopuszańskiego, nazywanego przez współpracowników Ministerstwa Wyznań Religijnych i Oświecenja Publicznego „Żelaznym kanclerzem oświaty”, a przez swoich kolegów „polskim Sokratesem”. Autorka prof. D. Koźmian (Uniwersytet Szczeciński) podkreślała w swoim wystapieniu, że przesłanie T. Łopuszańskiego ma wymiar uniwersalny. Mimo wielu zasług nie doczekał się jednak żadnej monografii opracowanej przez historyków wychowania.

Ośrodek gdański reprezentował prof. R. Grzybowski (AWF Gdańsk), który w bardzo ciekawy sposób omówił kwestię szkolnictwa prywatnego w Gdyni w latach Drugiej Rzeczypospolitej.

Z kolei ośrodek poznański zaprezentowała dr Justyna Gulczyńska (Uniwersytet im. A. Mickiewicza - Poznań). Autorka omówiła kwestie organizacji i rozwoju niepublicznego szkolnictwa średniego ogólnokształcącego w stolicy Wielkopolski okresu międzywojennego.

Dorobek pedagogiczny szkolnictwa salezjańskiego w Polsce przedstawił w swoim referacie dr L. Albański (Kolegium Karkonoskie - PWSZ - Jelenia Góra). Omówił w nim postać założycjela Salezjanów Jana Bosko i jego podstawy pedagogiczne $w$ wychowaniu dzieci i młodzieży, zwrócił także uwage na fakt, że dzisiejsze wychowanie to dialog wychowanka $z$ nauczycielem, to wychowanie do poszanowania każdej osoby. Podobna tematykę podjał w swoim wystapieniu dr Robert Jankowski (Uniwersytet Szczeciński) wygłaszając referat pt. „Szkoły salezjańskie w Szczecinie”.

W kolejnym referacie mgr Izabela Nowakowska (Uniwersytet Łódzki) zaprezentowała sylwetki kilku łódzkich szkół publicznych i niepublicznych przełomu XIX i XX wieku. Również wystapienie dr L. Pawelec (Akademia Świętokrzyska) dotyczyło niepublicznej średniej szkoły żeńskiej w Ostrowcu Świętokrzyskim (1906 - 1949).

W następnym referacie dr M. Posłuszna (Akademia Medyczna - Poznań) przedstawiła popularyzowanie wiedzy o zdrowiu w środowisku wiejskim na przykładzie organizacji młodzieżowych w okresie 20-lecia międzywojennego.

Ostatnie wystapienie koncentrowało się na omówieniu kwestii szkolnictwa niepublicznego na łamach czasopism pedagogicznych. Problematykę tę zaprezentowała w swoim referacie dr E. Marek (Uniwersytet Łódzki).

W drugim dniu konferencji wygłoszono 10 referatów. Obradom przewodniczyli: S. Garlicki i R. Rosa. Otworzył je bardzo ciekawy referat prof. W. Goriszowskiego (WSP TWP - Warszawa) na temat determinantów rozwoju szkolnictwa niepublicznego w Polsce. Autor podkreślał w nim znaczenie jakości kształcenia dla potrzeb spoleczeństwa i lepszych perspektyw. Kolejnym mówcą była dr K. Kamińska (Uniwersytet Łódzki), która omówiła funkcjonowanie przedszkoli publicznych i niepublicznych w Polsce. Kontynuacja tego interesującego wystapienia były rozważania dr K. Dutkiewicz (Uniwersytet Łódzki) na temat specyfiki pracy wychowawczej nauczycieli świeckich w przedszkolach katolickich.

Po przerwie na kawę problem edukacji wczesnoszkolnej w szkołach niepublicznych podjęła mgr G. Grzędziel. Autorka w swoim referacie mówiła o potrzebie funkcjonowania tych placówek dla dobra dziecka chorego.

Kolejnym prelegentem była mgr K. Bandyra (Szkoła Podstawowa w Izdebnie Kościelnym), która przedstawiła genezę i działalność szkoły niepublicznej Klubu Inteligencji Katolickiej w Podkowie Leśnej. Podobną tematykę podjał w swoim wystapieniu mgr M. Woźniak - sponsor konferencji (Zespół Szkół Prywatnych w Łodzi), który omówił swoje doświadczenia w prowadzeniu szkoły prywatnej.

Działalność i funkcjonowanie Wyższej Szkoły Informatycznej w Łodzi przybliżyła uczestnikom konferencji prof. W. Leżańska (Uniwersytet Łódzki i Wyższa Szkoła Informatyczna w Łodzi).

Kolejnym mówca był prof. H. Małecki (Wyższa Szkoła Informatyki w Łodzi), który w swoim referacie omówił problem elastyczności toku studiów, koncentrując się na punktowym systemie kredytowym. 
Ostatni referat $w$ drugim dniu obrad przedstawił prof. T. Jałmużna (Uniwersytet Łódzki). Wystapienie dotyczyło aktualnych tendencji w badaniach nad szkolnictwem niepublicznym w Polsce.

Następnie wywiązała się dyskusja poświęcona problemom i kontrowersjom wokół szkolnictwa niepublicznego i państwowego w Polsce.

Podsumowania konferencji dokonał prof. T. Jałmużna. Uznał on konferencję za udaną. Podkreślił, że toczące się dyskusje upłynęły w sprzyjającej naukowym rozmyślaniom atmosferze a trwalym rezultatem konferencji będzie z pewnościa odpowiednia publikacja pokonferencyjna.

Matgorzata Postuszna

\section{Konferencja „W kręgu edukacji, nauki o niej i społeczeństwa”, 18 listopada 2002}

W stolicy Wielkopolski, w Poznańskiej Alma Mater, 18 listopada 2002 roku, miało miejsce ważne wydarzenie-konferencja pt. „W kręgu edukacji, nauki o niej i społeczeństwa”, której szczególny charakter został nakreślony przez wieloaspektowe obszary pracy naukowej prof. zw. dra hab. Kazimierza Denka.

Celem ogólnopolskiego spotkania było określenie miejsca zajmowanego przez edukację i nauki zajmujace się nią.

Obrady podzielone zostały na dwie części. Specyfika pierwszej związana była z obchodami 70-lecia urodzin i 45-lecia pracy naukowej prof. Kazimierza Denka. Uroczystość prowadzil prof. Eugeniusz Piotrowski. Po wysłuchaniu Gaude Mater Polonia w wykonaniu Chóru Kameralnego Collegium Posnaniensae pod dyrekcja prof. Barbary Nowak, JM Rektor UAM prof. Stanisław Lorenc uznajac Jubileusz prof. K. Denka za święto nadzwyczajne Uniwersytetu, zainaugurował konferencję. JM podziękował Jubilatowi za to, czym ubogacał przez wiele lat współpracowników, przyjaciól, studentów, m. in. za stworzenie fundamentów szkoły naukowej oraz za znaczny wpływ na obecny i przyszły kształt UAM.

Specjalnie dla Jubilata wystapił Zespół Kameralny Akademii Muzycznej, który zaprezentował utwór Mozarta.

Laudację pt. „Życie twórcze zaangażowane, nastawione na zmianę i edukacyjny dialog” wygłosił prof. Janusz Gnitecki. Zwrócił szczególną uwage na umiejętność łączenia przez Jubilata funkcji teoretyka i transformatywnego praktyka edukacji szkolnej. Przypominając najważniejsze etapy życia prof. K. Denka, porównał jego losy do egzystencji legendarnego Króla Ducha. Ponadto prelegent scharakteryzował zakresy pracy badawczej Jubilata. Najważniejszy z nich dotyczy edukacji w szkole, której prof. K. Denek poświęcił zarówno metodyczne, jak i teoretyczne teksty, dotyczące również znaczenia turystyki i krajoznawstwa w procesie wychowawczym i dydaktycznym. Pozostale obszary pracy naukowej obejmuja $\mathrm{m}$. in. zagadnienia zwiazane z: dydaktyka ogólną i teorią kształcenia (cele, środki, metody, pomiar), reforma szkolnictwa (strategia reformy, pozycja szkoły w przemianach ustrojowych), wartościami i celami edukacji szkolnej, kształceniem i dokształcaniem zawodowym nauczycieli, metodologią badań pedagogicznych, przemianami i watkami edukacyjnymi w Polsce i na świecie. Prof. J. Gnitecki charakteryzując dorobek naukowy prof. K. Denka, zwrócił również uwagę na jego najnowsze pozycje książkowe: „Aksjologiczne aspekty edukacji szkolnej”, „W kręgu edukacji, krajoznawstwa i turystyki w szkole”, „Poza lawka szkolna”.

Po krótkiej przerwie wyrazy sympatii oraz życzenia przekazali Jubilatowi goście, $m$. in.: prof. T. Lewowicki (Komitet Nauk Pedagogicznych), prof. S. Juszczyk, prof. W. Koiss (Uniwersytet Śląski), prof. T. Kostrzyc (Akademia Wychowania Fizycznego - Wrocław), prof. W. Furmanek (Uniwersytet 